\title{
DETERMINANTS AND BARRIERS TO THE TOURISM DEVELOPMENT IN KALININGRAD OBLAST OF THE RUSSIAN FEDERATION AND WARMIA AND MAZURY REGION
}

\author{
IWONA M. BATYK \\ University of Warmia and Mazury in Olsztyn, POLAND \\ e-mail: iwona.batyk@uwm.edu.pl
}

\begin{abstract}
KEYWORDS $\mid$ Kaliningrad Oblast of the Russian Federation, tourism, cross-border cooperation, determinants and barriers to development

ABSTRACT Kaliningrad Oblast of the Russian Federation is important for tourism development in the Polish border regions. The convenient location of the Kaliningrad Oblast contributes to the organization of promotion and sale of Polish tourist services.

The study contains the results of research, which aim was to identify areas with significant development perspectives for the Polish-Russian borderland. Based on survey, conducted among Russians, identified determinants of tourism development on the Polish-Russian borderland and barriers for the development.
\end{abstract}

\section{Introduction}

During the global crisis, Kaliningrad District of the Russian Federation is recognized by economists as being of great economic potential and tourism. Kaliningrad Oblast is unique among the constituent parts of the Russian Federation due to its small size and its location as an exclave with relatively open borders on the surrounding states and as Russia's western most region. Furthermore, Kaliningrad Oblast is more exposed to foreign influence than other Russian regions, 
and people travel more to the adjacent countries than to Russia. Europe has a big cultural impact on the region. The development of Kaliningrad Oblast and its status depends on the general economic situation and the authoritarian political system in Russia, but more than in other Russian regions, Western countries have an impact on this development (Oldberg, 2001, p. 72).

The progressive political and economic changes have contributed to the rapid development of cooperation and building new relationships. Especially quickly this cooperation began to develop after 2012 when he started to operate a small border traffic. The cross-border cooperation between Poland and Russia concerns the exchange of commercial, service and tourism.

The development of cross-border cooperation is not a competition for the regions, but a complement or economic conditions creating the basis for their operation. This cooperation allows for close-up and associate business partners, finding new markets and the increase in trade (Białobrzeska, Kisiel, 2003, p. 104).

The study contains the results of research, which aim was to identify areas with significant development perspectives for the Polish-Russian borderland. Based on survey, conducted among Russians, identified determinants of tourism development on the Polish-Russian borderland and barriers for the development.

\section{Factors affecting the development of border tourism}

Tourism is one of the key factors of economic development for many countries and regions in the world, which produces a powerful effect on economic activities within various business areas. Tourism contributes to the national wealth by producing material values through putting tourist facilities into operation, developing infrastructure, etc. (Kornak, 1997, pp. 158-159).

Tourism is one of the most important factors of economic development. The economic benefits of tourism development relate to aspects (Kurek, 2007, pp. 409-410):

- investments in tourism infrastructure,

- development of entrepreneurship in the tourism sector or other related to it,

- creation of new employment opportunities.

Tourism policy is to determine the economic, political, social and cultural activities related to the tourism development, to achieve positive financial results, satisfaction of social needs (Wodejko, 1998, p. 170). Once largely a consequence of wars and colonization, culture change today results from international trade and finance, global media and technological flows, immigration, and business and tourism (Appadurai, 1990). Therefore, exposure to the foreign cultures requires to travel.

International tourism in the Kaliningrad Oblast started after 1990, when the region opened to foreigners. After EU enlargement the Kaliningrad region hasn't managed to fully exploit the possibilities provided by its unique nature, history and geographical position. Various issues slow down the building of the tourism industry in the region, such as undeveloped international transport connections, the small number of Western-standard hotels and visa requirements between the EU and Russia (Pursiainen, Medvedev, 2005, p. 80). In 2008, the Kaliningrad Oblast was visited by 95,000 
foreign tourists. In the next years it was much less foreigners visiting Kaliningrad, there were 53,000 in 2010. Half of the foreign tourists were from Germany, $18 \%$ form Poland and 12\% from the Baltic countries (Anasiewicz, Palmowski, 2014, pp. 79-86). Western tourists were scared away by the fact, that the region itself offered only a small and poor market, and its attractiveness largely depended on free access to the rest of Russia (Wenger, Perovic, 2001, p. 31). Renewed interest in tourist travels to the Kaliningrad Oblast was in 2012, when the small border traffic started between Poland and Russia. It affected the great interest traveling abroad by the Russian and Polish citizens.

The agreement on small border traffic defines the rules of crossing the Polish-Russian border, which is also the border of the European Union. Small border traffic includes part of the Pomerania and Warmia an Mazury Voivodship and the Kaliningrad Oblast. The location and socio-economic factors affect on the formation of Polish-Russian regional cooperation. This cooperation is realized on many levels, which include mainly trade and tourism.

For both Polish and Russian residents, this agreement creates many opportunities for business, tourism, etc. Moreover, interregional cooperation should contribute to removing barriers to movement of goods and services, tourism development, and trade. Joint projects are also meant to support technology and knowledge exchange. Now, the most important role in Polish-Russian relations is to exchange services. Poland is a major exporter of services in tourism, medicine and construction (Batyk, Semenova, 2013, pp. 77-85).

By 2014, cross-border cooperation between Poland and Russia favored economic integration, the development of many sectors of the economy. This integration caused a correlation between the neighboring countries, eg. in the area of implementation of joint tourism projects and tourism events as kayaking from Olsztyn to Kaliningrad. Among the benefits brought cross-border cooperation include: improving the environment, modernizing and increasing the efficiency of public infrastructure, enterprise development, increased tourism, development of better neighborly relations, increasing trade and the revival of cultural exchange.

In 2014 there was a significant crisis in regional cooperation caused by political and economic factors. Also, this crisis was very painful for the travel industry. Purchasing power of the Russian currency decreased, which resulted in less interest Polish tourist services by the Russians. The year 2014 was for the tourism business much worse than the crisis year 2009. The number of tourist trips decreased by 20-25\%. In 2014, demand for foreign trips of Russian travel agencies decreased by $50-70 \%$ (Analiza..., 2015, pp. 134-152). The most important factor influencing the less interest Russian tourist trips was a reduction in the value of the ruble (in December 2014 a reduction of $50 \%$ relative to the dollar and euro). For many Russians, foreign trips were impossible. Even if the Polish entrepreneurs of the tourism industry, offer a variety of discounts and promotions, they can not get the sale of tourist services of that in 2012 and 2013 year. Unfortunately, the crisis continues.

The crisis in Polish-Russian relations affects not only social relations but has mostly negative affects on tourism businesses. Tourism enterprises are creating an overall quality of the total tourism product, so they are engaged in common marketing process which is not trouble-free since tourism industry is, in spite of few mainly transportation enterprises and chain hotels, mostly composed of small and medium companies (Pawlicz, 2007, pp. 257-264). 


\section{Determinants and barriers of the tourism development in the Kaliningrad Oblast and Warmia and Mazury region}

The study aimed to identify the areas of greatest development opportunities for PolishRussian borderland, determinants of tourism development and barriers to its development, conducted in 2012 among 200 residents of Kaliningrad Oblast. Respondents were chosen using random selection. The study used a method of face-to-face survey. The research tool was a questionnaire. Presented in this paper results are a part of a wider research. The study involved $50 \%$ of women and 50\% men. Respondents declared higher education (30\%), secondary education (21\%), bachelor (21\%), vocational education (19\%) and primary education (9\%). The largest group of respondents participating in the study were people aged 36-45 years $(25.5 \%)$ and $18-25$ years $-25 \%$. Persons aged 26-35 years accounted for $17.5 \%$ of the respondents. Next groups of respondents in terms of numbers were: persons aged 46-55 years (22\%) and over 55 years (10\%). Differentiation also related to social status. One in five respondents had their own businesses (20\%), 30\% of respondents were employed, government employees $-14.5 \%$, unemployed $-9 \%$ of students $-20 \%$ and pensioners $-6.5 \%$.

The research shows, that the areas with the greatest perspectives for development of cooperation between the Kaliningrad Oblast and the Warmia-Mazury province are: tourism (31.8\% of responses), the exchange of goods (31.7\%) and joint ventures economic and social (17.5\%). PolishRussian cross-border cooperation causes little impact on technological development (5.2\%), reducing the negative stereotypes (5.8\%) and unemployment (8\%).

Results of this study identified the determinants of the tourism development in the border regions (Figure 1). According to the Russians, tourism development in the Kaliningrad Oblast is affected by: location (22.3\% of responses), the environment (15\%) and transport availability (12.7\%). Least the tourism development in the Kaliningrad Oblast is affected by: prices $(1.3 \%)$, cultural events and sports (1.7\%) and active leisure (2\%).

Respondents pay attention to the lack of tourist attractions that would encourage tourists to stay in Kaliningrad Oblast. In addition, the use of the Baltic Sea (which for some Russians is still the biggest attraction) is not attractive form of tourism. The tourism product, which is the subject of supply on the tourism services market, can be diversified and it is most often defined as a package of material and nonmaterial elements that contribute to the realization of a tourist trip (Marciszewska, 2010, p. 42).

The important determinants of tourist products include tourist attractions, which should lead to the development of the tourism industry. Unfortunately, in the Kaliningrad Oblast, there are no tourist products that provide attractive leisure, and the prices of tourist services are disproportionate to their quality.

For the Russians, the most important factors affecting the tourism development in the WarmiaMazury are (Figure 1): attractive prices of tourism services (18.7\% of responses), high level and variety tourist accommodation (17.7\%), spa services (11.7\%) and the values of the environment (14\%). The most important element of the tourist offer is accommodation, which also has additional 
functions. Russians are very eager to use tourist accommodation, which in addition to the accommodation service provides extra services (Meyer, Panasiuk and Sawińska, 2013, pp. 131-145). Often, they stressed the importance of water attractions, spa facilities, cosmetic procedures, boat rides and cruises sailing. Hoteliers are aware of the growing demand for Spa service and consider it as a key way to build their competitiveness (Rapacz and Jaremen, 2013, pp. 107-121).

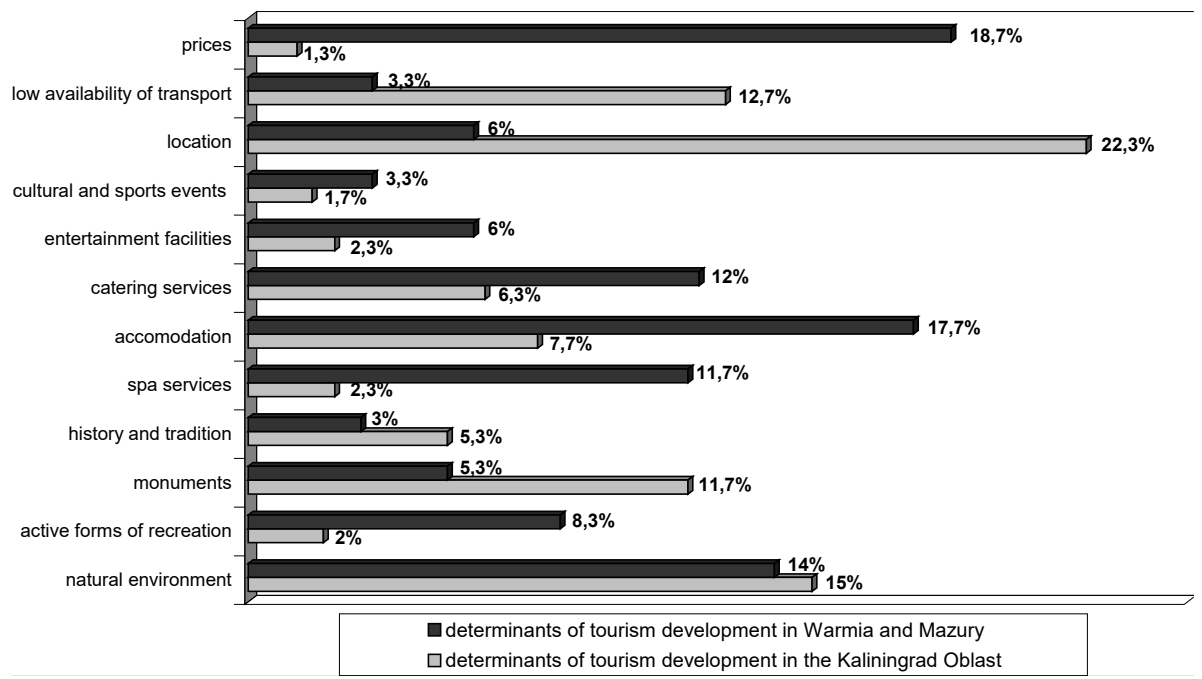

Figure 1. Determinants of the tourism development in the Kaliningrad Oblast and Warmia and Mazury region Source: own study.

One of the tourists trends is diversification of tourist needs connected to different expectations of various tourist groups (examined from the point of view of different nationalities and societies) and a stable growth of demand for tourism services, which changes faster than the travellers growth suggests (Meyer, 2014, pp. 135-148). The Russians drew attention to the flexible creation of the tourist offer and composition it to the needs of tourists. For the offer created for their needs are the want to pay a high price. Price is considered by Russians as a tool for creating attractive tourism product. Paradoxically, the higher the price of services the higher the interest in these services is.

The Russians say, that the least impact on the tourism development in the Warmia-Mazury region are: history and tradition (3\% of responses), cultural and sporting events $(3.3 \%)$ and transport availability (3.3\%).

The results showed the importance barriers to the tourism development in the Kaliningrad Oblast (Figure 2): high prices of services (22.7\% of responses), poor quality of service (21\%), low availability of communication (15\%) and the lack of attractive offer tourist services (10.7\%). The high prices of tourist services in connection with the low level of services do not encourage visitors from other countries and residents of the Kaliningrad Oblast to use these services. 
Residents of the Kaliningrad Oblast prefer tourist trips to Poland, where they can enjoy more attractive range of services. When it comes to Russians buying local brands, consumers base their purchases primarily on price and perceived image.

Important barriers for the tourism development in the Warmia and Mazury are: visa procedures $(23 \%$ of responses), language barriers (15.6\%) and administrative procedures (13\%). The Russians pay attention for a long time waiting for documents allowing to cross the border. Mass interest in trips to Poland, after the start of the small border traffic, caused difficulties of access to consular posts.

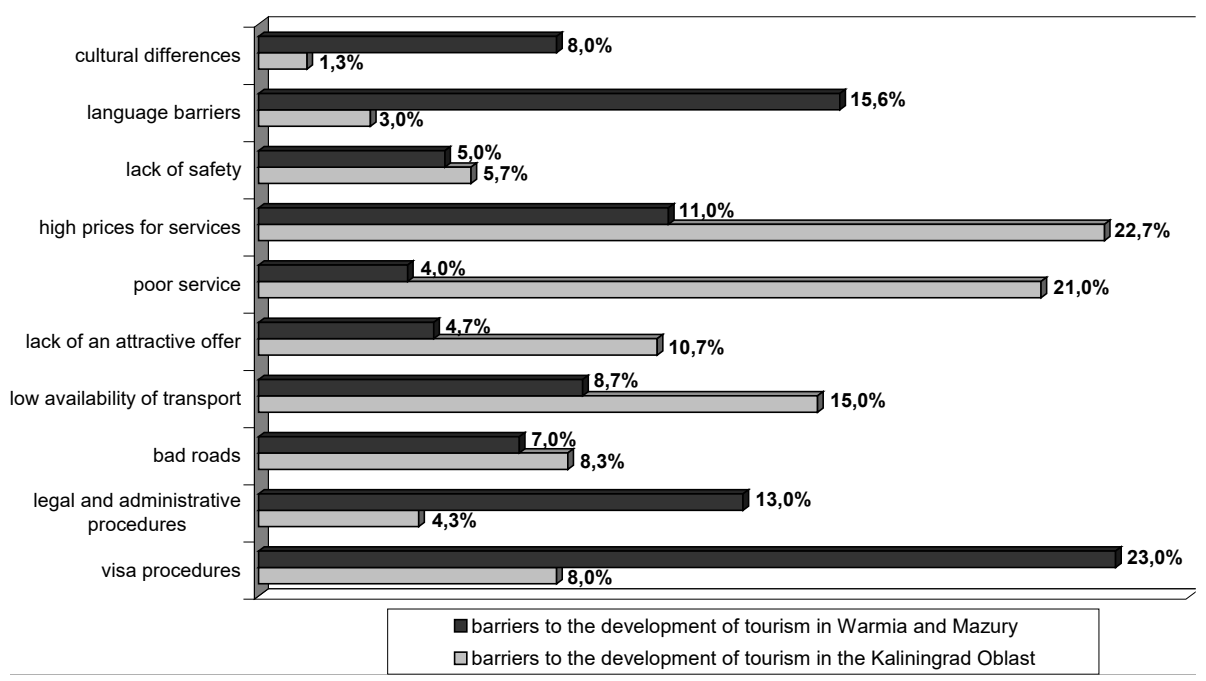

Figure 2. The barriers to the tourism development in the Kaliningrad Oblast and Warmia and Mazury region Source: own study.

The results of these studies are encouraging for many businesses of the tourism industry to develop a service offer for Russian customers and profiling of these services to the needs of specific tourist. Since the start of the small border traffic, there was a significant increase in tourists from Russia using the hotel facilities. Hotels that provide spa services were very popular among Russians. As a result, in the border regions have built new objects with services for the Russians dedicated. The Russians were frequent guests of these objects. That situation was to the first quarter of 2014 when there was a significant reduction in the value of the Russian currency. The quality and variety of tourism services provided in Poland is still very attractive for the Russians, but the barrier is the price of these services. The consumer acculturation theory suggests that the full convergence of the Russian market with the West is rather unlikely, and as a consequence that tourism companies will have to manage more and more complex layers and categories of cultural change and consumption styles (Prime, Triers, 2012). 


\section{Conclusions}

The tourism development between the Warmia and Mazury Voivodeship and the Kaliningrad Oblast are affected by many factors, both external and internal. These are mainly restrictions on border crossings, administrative procedures, disparities in economic and cultural differences. The development of tourist services will depend on the evolution of these factors.

Current relations between Poland and Russia are dominated by political factors related to the conflict in Ukraine. The future of Polish-Russian tourists cooperation and development of the border regions will depend on political events, the scale and dynamics is difficult to predict. Normally, negative experiences are in the public consciousness for a long time, it is difficult to convert into a positive experience. Back to slight stabilization in Polish-Russian relations that Polish entrepreneurs experienced in 2012-2014 will not be an easy task and it will not be soon.

For Polish entrepreneurs and manufacturers of products and services is a major challenge. Despite the unfavorable geo-political situation, they try to gain the confidence of tourists from Russia by providing its services at the highest possible level and the creation of an atmosphere of mutual trust. If they still find ways to use the media in order to offer their product or service, there is a strong potential to generate business. To create this interest efforts are needed entrepreneurs and state and local authorities.

\section{Referencences}

Analiza rynków za rok 2014 objętych działaniami zagranicznych ośrodków Polskiej Organizacji Turystycznej (2015). Warszawa: Polska Organizacja Turystyczna.

Anasiewicz, R., Palmowski, T. (2014). Small border traffic and cross-border tourism between Poland and the Kaliningrad Oblast of the Russian Federation. Quaestiones Geographicae, 33 (2), 79-86.

Appadurai, A. (1990). Disjuncture and difference in the global cultural economy. In: M. Featherstome (ed.), Global Culture: nationalism, globalization and modernity. London: Sage.

Batyk, I., Semenova, L. (2013). Cross-border cooperation in tourism between the Warmian-Masurian Voivodship and the Kaliningrad Oblast. Baltic Region, 3 (17), 77-85.

Białobrzeska, R., Kisiel, R. (2003). Wspótpraca transgraniczna wschodnich regionów Polski. Olsztyn: UWM Olsztyn.

Kornak, A.S. (1997). Ekonomika turystyki. Bydgoszcz: Kujawsko-Pomorskie Studium Edukacyjne.

Kurek, W. (2007). Turystyka. Warszawa: Wydawnictwo Naukowe PWN.

Marciszewska, B. (2010). Produkt turystyczny a ekonomia doświadczeń. Warszawa: C.H. Beck.

Meyer, B. (2014). Consumer behaviours on the tourism market. Scientific Journal No. 836, Economic Problems of Tourism, 4 (28), 135-148.

Meyer, B., Panasiuk, A., Sawińska, A. (2013). Baza noclegowa jako determinanta kreowania produktu turystycznego „Pomorska Droga Św. Jakuba” w województwie zachodniopomorskim. Zeszyty Naukowe Uniwersytetu Szczecińskiego nr 785, Ekonomiczne Problemy Turystyki, 4 (24), 131-145.

Oldberg, I. (2001). Kaliningrad: Russian exclave, European enclave. Stockholm: Swedish Defence Research Agency.

Pawlicz, A. (2007). Destination promotion as an example of cooperation between private and public sector. Medium Baltic cities case. Scientific Journal, 457, Service Management, 1, 257-264.

Prime, N., Triers, A. (2012). The Russian Consumer Behaviour 20 Years After The Fall of Communism: Insights from Consumer Acculturation Theory. Proceedings of the International Marketing Trends Conference, University of Venice, Italy. 
Pursiainen, Ch., Medvedev, S. (2005). Towards the Kaliningrad Partnership in EU-Russia Relations: A Road Map into the Future. Moscow: Russian-European Centre for Economic Policy.

Rapacz, A., Jaremen, D.E. (2013). Znaczenie usług spa \& wellness w budowaniu przewagi konkurencyjnej przedsiębiorstw hotelarskich - Case study hoteli uzdrowiskowych w Świeradowie-Zdroju. Zeszyty Naukowe Uniwersytetu Szczecińskiego nr 784, Ekonomiczne Problemy Turystyki, 3 (23), 107-121.

Wenger, A., Perovic, J. (2001). Russland zwischen Zerfall und Grossmachtanspruch. Herausforderung der Regionalisierung. Forschungsstelle für Sicherheitspolitik und Konfliktanalyse, 47, 31.

Wodejko, S. (1998). Ekonomiczne zagadnienia turystyki. Warszawa: Wyższa Szkoła Handlu i Prawa.

\section{DETERMINANTY I BARIERY ROZWOJU TURYSTYKI \\ W OBWODZIE KALININGRADZKIM FEDERACJI ROSYJSKIEJ \\ ORAZ W REGIONIE WARMII I MAZUR}

\footnotetext{
SŁOWA KLUCZOWE $\mid$ Obwód Kaliningradzki Federacji Rosyjskiej, turystyka, współpraca przygraniczna, determinanty i bariery rozwoju

STRESZCZENIE

Obwód Kaliningradzki Federacji Rosyjskiej ma istotne znaczenie dla rozwoju turystyki w polskich regionach przygranicznych. Dogodna lokalizacja Obwodu Kaliningradzkiego przyczynia się do organizacji promocji i sprzedaży polskich usług turystycznych.

Opracowanie zawiera wyniki badań, których celem była identyfikacja obszarów o największych perspektywach rozwoju na polsko-rosyjskim pograniczu. Na podstawie badań przeprowadzonych wśród Rosjan, określono determinanty rozwoju turystyki na polsko-rosyjskim pograniczu oraz bariery jej rozwoju.
} 